\title{
Weaning affects lipoprotein lipase activity and gene expression in adipose tissues and in masseter but not in other muscles of the calf
}

\author{
Jean-François Hocquette*, Benoît Graulet, Michel Vermorel and Dominique Bauchart \\ Unité de Recherches sur les Herbivores, Institut National de la Recherche Agronomique, Centre de Recherches de Clermont \\ Ferrand-Theix, 63122 Saint-Genès-Champanelle, France \\ (Received 9 November 2000 - Revised 8 May 2001 - Accepted 9 June 2001)
}

\begin{abstract}
The nutritional and physiological modifications that occur during the weaning period induce adaptations of tissue metabolism in all mammal species. Among the adaptations due to weaning in ruminants, the regulation of lipoprotein lipase (LPL) activity, one of the rate-limiting steps of fatty acid utilization by tissues, was still unknown. The present study aimed at comparing LPL activity and gene expression in the heart, seven skeletal muscles and three adipose tissue sites between two groups of seven preruminant $(\mathrm{PR})$ or ruminant $(\mathrm{R})$ calves having a similar age $(170 \mathrm{~d})$, similar empty body weight $(194 \mathrm{~kg})$ at slaughter, and similar net energy intake from birth onwards. Triacylglycerol content of adipose tissues was $16 \%$ lower in $\mathrm{R}$ than in PR calves, $(P<0.01)$. This could be partly the result from a lower LPL activity $(-57 \%, P<0.01)$. LPL mRNA levels were also lower in $\mathrm{R}$ calves $(-48 \%$ to $-68 \%, P<0.01)$ suggesting a pretranslational regulation of LPL activity. Activity and mRNA levels of LPL did not differ significantly in the heart and skeletal muscles except in the masseter in which LPL activity and mRNA levels were higher $(+50 \%$ and $+120 \%$ respectively, $P<0 \cdot 01)$ in the $\mathrm{R}$ calves. Regulation of LPL in masseter could be explained by the high contractile activity of this muscle after weaning due to solid food chewing. In conclusion, weaning in the calf affects LPL activity and expression in adipose tissues, but not in skeletal muscles except the masseter.
\end{abstract}

Lipoprotein lipase: Muscle: Adipose tissue: Weaning: Bovine

From birth to weaning, neonates suckle maternal milk or receive exclusively a milk-based diet to meet their energy needs. During the first weeks of life, feed intake must be sufficient and regular to allow for the rapid development of organs (such as digestive tract, brain, liver and kidney). This period is also characterised by a high rate of protein accretion in skeletal muscles that allows rapid body growth when the dietary energy and $\mathrm{N}$ supply is satisfactory.

Thereafter, the suckling-weaning transition is the most deep nutritional change that the animal has to face in its life. In the rat, the high-fat and low-carbohydrate milk diet is replaced by a carbohydrate-rich and low-fat diet. A great number of studies has been carried out in this model to demonstrate the regulation of tissue energy metabolism by nutritional changes (for review, see Girard et al. 1992).

However, the weaning-suckling transition differs markedly between ruminant animal species such as bovines, and single-stomached species such as man and rats. Indeed, at weaning, fat and carbohydrates, the major energy-yielding substrates for the young calf, are replaced by volatile fatty acids, mainly acetate, and ketone bodies produced by the bacterial fermentation of solid foods in the rumen. Thus, weaning in ruminant animals is a specific and interesting model to study the nutritional regulation of energy metabolism. However, most of the experimental data published so far about weaning in ruminant animal species have concerned the development of the ruminal functions or the changes in plasma metabolites and hormones (Kouame et al. 1984; Quigley et al. 1991a,b). Only two studies in the bovine at weaning showed lower activities of glycolytic enzymes and glucose-6-phosphate dehydrogenase and higher activity of acetyl-CoA synthetase in the liver (Pearce $\&$ Unsworth, 1980) and lower activity of lactate dehydrogenase in skeletal muscles (Hocquette et al. 1997). However, no data are available about the regulation of the bovine lipoprotein lipase (LPL) activity at weaning, although this enzyme is considered as a key step for fatty

\footnotetext{
Abbreviations: LPL, lipoprotein lipase; OAT, omental adipose tissue; PAT, perirenal adipose tissue; PR, pre-ruminant; R, ruminant; SCAT, subcutaneous adipose tissue; TAG, triacylglycerol.

* Corresponding author: Dr Jean-François Hocquette, fax +33 4736246 39, email hocquet@clermont.inra.fr
} 
acid uptake by peripheral tissues (mainly adipose tissues and muscles) from circulating triacylglycerols (TAG) (for review, see Hocquette et al. 1998b). LPL activity is subject to complex hormonal and nutritional tissue-specific regulations that have been mainly studied in rodents (Olivecrona et al. 1991).

The cDNA of the bovine LPL has been cloned in the last decade (Senda et al. 1987). The expression of the bovine LPL gene has been studied in the mammary gland (Senda et al. 1987), in adipose tissues (Bonnet et al. 1998) and in skeletal muscles (Hocquette et al. 1998a). Meanwhile, a method to assay LPL activity was also optimized in bovine tissues by using rat serum as source of LPL activator (Hocquette et al. 1998a).

The aim of the present work was to investigate the regulation of LPL activity and gene expression in adipose tissues and skeletal muscles in the calf at weaning. Marked changes in LPL activity were firstly hypothesised as results of a lower dietary fat supply after weaning and of major differences in levels of plasma metabolites and hormones between milk-fed calves and weaned calves. However, we observed differences in LPL activity and expression in adipose tissues and in masseter muscle only, and not in other muscles of the carcass.

\section{Material and methods}

\section{Reagents}

$\left[{ }^{3} \mathrm{H}\right]$ Triolein $(1.85-2.96 \mathrm{GBq} / \mathrm{mmol})$ and Hyperfilms MP were supplied by Amersham International (Amersham, Bucks., UK). [ $\left[\alpha-{ }^{32} \mathrm{P}\right]$ deoxy-cytidine-5'-triphosphate $(>111 \mathrm{TBq} / \mathrm{mmol})$ and $\left[\gamma^{32} \mathrm{P}\right]$ deoxy-adenosine-s'-triphosphate $(>111 \mathrm{TBq} / \mathrm{mmol})$ were purchased from ICN Biochemicals (Irvine, CA, USA). Guanidium thiocyanate was obtained from Fluka (Ronkonkoma, NY, USA). Genescreen membranes were from New England Nuclear Life Science Products (Boston, MA, USA). T4 polynucleotide kinase was supplied by New England Biolabs Inc. (Beverly, MA, USA). Saturated phenol, chloroformisoamyl alcohol (49:1, v/v), agarose and nonaprimer labelling kit were purchased from Appligène (Illkirch, France). RNA molecular-mass-markers were from Bethesda Research Laboratories (Bethesda, MD, USA) Other reagents were from Sigma (St Louis, MO, USA).

\section{Animals and experimental design}

The fourteen Montbéliard male calves used were the animals described in a previous paper (Hocquette et al. 1997). They were tied and housed in individual stalls at ambient temperature in a room with natural lighting. Animals were allotted at the age of $88 \mathrm{~d}$ on the basis of live weight, average daily weight gain and average nutritional efficiency. From birth to $107 \mathrm{~d}$ of age, animals were maintained on a standard milk-substitute diet. From $107 \mathrm{~d}$ to slaughter, preruminant (PR) calves of the first group were fed individually on a commercial milk-substitute diet. Fat, carbohydrates and protein provided 35, 40 and $25 \%$ absorbed energy respectively. Net energy intake was assessed from feed intake and net energy value of the milk-substitute diet. The latter was calculated from chemical composition, metabolizibility and the efficiency of metabolizable energy utilisation of similar diets in PR of similar body weight (Vermorel et al. 1974). Animals of the second group were progressively weaned from 107 to $128 \mathrm{~d}$ of age and became ruminant $(\mathrm{R})$ calves. These calves were fed individually a mixed diet composed of $800 \mathrm{~g}$ concentrate and $200 \mathrm{~g}$ hay $/ \mathrm{kg}$, according to a feeding pattern designed to allow an average daily gain of $1300 \mathrm{~g}$. Fat, carbohydrates, proteins and volatile fatty acids were assumed to provide approximately 8, 2, 25 and 65-70\% absorbed energy respectively, according to previous estimations (Hocquette et al. 1997). Net energy intake was calculated from feed intake and the tabulated net energy values of the feed ingredients (Jarrige, 1989). The rate of feeding was adjusted weekly so that net energy intakes from birth onwards were similar for the two groups of animals.

Calves were slaughtered at $170 \mathrm{~d}$ of age, after a $16 \mathrm{~h}$ overnight fast. Tissue samples $(50-100 \mathrm{~g})$ were always taken at the same site for all animals to minimise sampling error: heart, masseter, diaphragma, rectus abdominis, longissimus thoracis commonly designated longissimus dorsi (Kauffman et al. 1990), semitendinosus from the medial part, tensor fasciae latae, cutaneus trunci from the thick part, perirenal adipose tissue (PAT), omental adipose tissue (OAT) and subcutaneous adipose tissue (SCAT).

Muscle tissue samples were quickly trimmed of visible fat and connective tissue, cut into pieces, frozen in liquid $\mathrm{N}_{2}$ in less than $10 \mathrm{~min}$ post-exsanguination and stored at $-80^{\circ} \mathrm{C}$ for subsequent analysis. Adipose tissue samples were quickly cut into pieces, and then frozen at $-80^{\circ} \mathrm{C}$ either in homogenization buffer for LPL assay (Hocquette et al. $1998 a$ ) or in liquid $\mathrm{N}_{2}$ and stored at $-80^{\circ} \mathrm{C}$ for subsequent analysis (Hocquette et al. 1997). Frozen samples were pulverized in liquid $\mathrm{N}_{2}$ to get an homogeneous powder before any treatment.

\section{Analytical techniques}

Blood samples were taken from the jugular vein after a $16 \mathrm{~h}$ overnight fast before slaughter. They were then centrifuged at $3500 \mathrm{~g}$ for $10 \mathrm{~min}$ at $15^{\circ} \mathrm{C}$. Packed cell volume was measured after centrifugation of blood samples. Plasma samples were kept at $-20^{\circ} \mathrm{C}$ until assayed. Commercial kits were used to determine plasma concentrations of insulin (INSIK-5 P2796; Sorin Biomedica, Saluggia, Italy), triiodothyronine (Amerlex - M T3 RIA; Amersham International), non-esterified fatty acids (Wako kit, Unipath S.A., Dardilly, France), glucose and TAG (PAP 250 ref 61271 and PAP 150 ref 61236 respectively; BioMérieux, Marcy-1'Etoile, France). Protein and DNA contents in muscles and in adipose tissues and activity of isocitrate dehydrogenase in muscles, were determined as previously described (Hocquette et al. 1996, 1997).

\section{Assay of lipoprotein lipase activity}

LPL activity was assayed after detergent extraction as previously described (Hocquette et al. 1998a). Frozen muscle tissue powder or frozen adipose tissue pieces (approximately $4 \mathrm{~g}$ ) were homogenized at $4^{\circ} \mathrm{C}$ in $9 \mathrm{ml}$ 
buffer/g (buffer was composed of ammonia-HCl (25 mM), pH 8.2 containing EDTA (5 mM), Triton X-100 (8 g/l), SDS $(0 \cdot 10 \mathrm{~g} / \mathrm{l})$, heparin $(5000 \mathrm{IU} / \mathrm{l})$ and peptidase inhibitors [pepstatin A $(1 \mu \mathrm{g} / \mathrm{ml})$, leupeptin $(10 \mu \mathrm{g} / \mathrm{ml})$ and aprotinin $(0.017 \mathrm{TUI} / \mathrm{ml})]$. Insoluble material was discarded by centrifugation at $20000 \mathrm{~g}$ for $20 \mathrm{~min}$ and at $4^{\circ} \mathrm{C}$.

LPL activity was assayed with $4 \mu$ l tissue homogenate diluted 5-fold in water. The substrate emulsion was Intralipid (120 mM-TAG; Pharmacia \& Upjohn, Stockholm, Sweden) into which a trace amount of $\left[{ }^{3} \mathrm{H}\right]$ triolein had been incorporated by sonication $(75 \mathrm{~W}, 10 \mathrm{~min})$ using a Vibra Cell apparatus (Bioblock Scientific, Illkirch, France). Incubation medium, in which $20 \mu$ l diluted tissue homogenate was added, was composed of $10 \mu \mathrm{l}$ Intralipid emulsion, $10 \mu \mathrm{l}$ heat-inactivated rat serum as a source of apolipoprotein C-II (the natural activator of LPL activity), $60 \mu \mathrm{l}$ deionized water and $100 \mu \mathrm{l}$ incubation buffer. This buffer contained fatty acid free bovine serum albumin $(120 \mathrm{~g} / \mathrm{l})$, standard heparin $(0 \cdot 20 \mathrm{~g} / \mathrm{l}), 0 \cdot 2 \mathrm{M}-\mathrm{NaCl}$ and $0 \cdot 3 \mathrm{M}$-Tris- $\mathrm{HCl} \mathrm{pH} 8 \cdot 5$. The reaction was carried out for $60 \mathrm{~min}$ at $25^{\circ} \mathrm{C}$ in a shaking water bath. The reaction was stopped by addition of $500 \mu \mathrm{l}$ distilled water and $2 \mathrm{ml}$ isopropanol - heptane $-\mathrm{H}_{2} \mathrm{SO}_{4}$ (48:48:3:1, by vol.). Total lipids were extracted and fatty acids were separated from TAG with alkaline ethanol and heptane as previously described (Hocquette et al. 1998a). An aliquot of the remaining alkaline ethanol phase containing ${ }^{3} \mathrm{H}$-labelled fatty acids was counted by liquid scintillation.

LPL activity was the mean result from three incubations and was expressed in $\mathrm{mU} / \mathrm{g}$ wet tissue weight $(1 \mathrm{mU}=1 \mathrm{nmol}$ fatty acids released $/ \mathrm{min})$. Results were converted to $\mathrm{mU} / \mathrm{mg}$ tissue protein or $\mathrm{mU} / \mathrm{mg}$ tissue DNA.

\section{Quantification of lipoprotein lipase mRNA levels}

Total RNA were isolated using guanidium thiocyanate as previously described (Hocquette et al. 1996). The amount of RNA was determined by absorbance at $260 \mathrm{~nm}$. All samples had a 260:280 $\mathrm{nm}$ absorbance ratio of approximately $2 \cdot 0$. RNA were stored at $-20^{\circ} \mathrm{C}$ precipitated by $0 \cdot 1$ volumes $2 \mathrm{M}$-sodium acetate $\mathrm{pH} 5.0$ and 2.5 volumes ethanol. RNA aliquots $(40 \mu \mathrm{g})$ were washed by diethylpyrocarbonatetreated water $(250 \mathrm{ml} / 1)$ and ethanol $(750 \mathrm{ml} / 1)$, then denatured in a solution containing $2.2 \mathrm{M}$-formaldehyde and formamide $(500 \mathrm{ml} / \mathrm{l})$ by heating at $65^{\circ} \mathrm{C}$ for $10 \mathrm{~min}$. RNA were size-fractionated by $1.5 \%$ agarose gel electrophoresis. Their integrity was assessed by ethidium bromide staining before electrophoretical transfer to Genescreen membranes (New England Life Science Products) (Hocquette et al. 1996).

The bovine LPL probe (Senda et al. 1987) was kindly provided by Dr Y. Furuichi (Nippon Research Center, Kamakura, Japan) and it was labelled by random priming with ${ }^{32} \mathrm{P}$ using the nonaprimer labelling kit. Prehybridization and hybridization of blotted RNA were performed at $42^{\circ} \mathrm{C}$ in solutions containing formamide $(450 \mathrm{ml} / \mathrm{l})$ as previously described (Hocquette et al. 1996). Hyperfilm MP (Amersham International) were exposed to the membranes for $2-15 \mathrm{~d}$ at $-80^{\circ} \mathrm{C}$ with two intensifying screens. Quantification of LPL mRNA levels was performed with scanning densitometry (Hoeffer, San Fransisco, CA, USA).
Membranes were also hybridized with a probe for the rat $18 \mathrm{~S}$ ribosomal RNA, to quantify precisely the relative levels of total RNA loaded (Hocquette et al. 1996). Levels of LPL mRNA were expressed in arbitrary densitometric units after correction for variations in loaded RNA.

\section{Statistical analyses}

ANOVA of the data was done using the GLM procedure of Statistical Analysis Systems (1987, version 6; SAS Institute Inc., Cary, NC, USA). For each variable, the effects tested in the model included group $(\mathrm{G})$ of calves (PR, R), calf $(\mathrm{C})$ nested within groups, tissue (i.e. muscle (M) or adipose tissue $(\mathrm{AT}))$ and the interaction group $\times$ tissue $(\mathrm{G} \times \mathrm{M}$ or $\mathrm{G} \times \mathrm{AT})$. The $\mathrm{G}$ factor was tested against $\mathrm{C}$ factor within groups. The residual mean square was used as the error term for other effects. Results are expressed as means values with their standard errors (SEM $=\sqrt{\text { residual mean squares}}$ ) number of observations per treatment). Differences among groups (PR and $\mathrm{R}$ ) or between muscles or adipose tissues inside a group (PR or R) were tested using the StudentNewman-Keuls test with a probability of 0.05.

\section{Results \\ Experimental conditions and animal characteristics at slaughter}

Calves were bred as previously described by Hocquette $e t$ al. (1997). Briefly, the live body weight was similar for PR and R calves (57.3 (SEM 1.3) and 58.0 (SEM 1.2) kg respectively) at the beginning of the experiment at $18 \mathrm{~d}$ of age. At slaughter at $170 \mathrm{~d}$ of age, live body weight was significantly higher for the R calves than for the PR calves (217 (SEM 2.7) v. 202 (SEM 4.3) $\mathrm{kg}$ respectively, $P<0.05$ ). Average daily weight gain was similar between the beginning of the experiment (18-d-old) and the mid period of weaning (118-d-old) for PR and R calves (1040 (SEM 28) and 990 (SEM 32) g respectively), but significantly higher for the $\mathrm{R}$ calves than for the PR calves (1280 (SEM 52) v. 950 (SEM 36) g respectively, $P<0.001)$ between 118 and $170 \mathrm{~d}$ of age and slaughter. These differences were mainly due to a high rumen content in the weaned animals as indicated by the fact that the empty body weight at slaughter did not significantly differ between the two groups of calves (195 (SEM 5.0) and 193 (SEM 2.8) $\mathrm{kg}$ respectively). Total net energy intake during the experimental period did not significantly differ between PR and R calves. However, the carcass weight tended to be slightly lower for the $\mathrm{R}$ calves than for the PR calves (114 (SEM 1.8) v. 121 (SEM 3.0) kg respectively, $P<0 \cdot 10)$.

No significant differences between PR and R calves were found in packed cell volume. Plasma glucose and TAG levels were also similar in both calf groups (results not shown). However, the plasma non-esterified fatty acid level was higher in $\mathrm{R}$ than in $\mathrm{PR}$ calves $(+45 \%, P<0.05)$. The plasma insulin level tended to be lower $(-23 \%, P<0 \cdot 10)$ and plasma triiodothyronine level was significantly lower $(-40 \%, P<0.001)$ in $\mathrm{R}$ calves than in PR calves (results not shown). 


\section{Biochemical characteristics of adipose tissues}

Total protein and DNA contents were higher $(+30 \%$ to $+120 \%, P<0.05)$ in SCAT than in internal adipose tissues (PAT and OAT). In adipose tissues of R calves, mean total protein content tended to be higher $(+18 \%)$ and mean DNA content was higher $(+35 \%)$ than in adipose tissues of PR calves $(P<0 \cdot 05)$, the difference being the most significant in the SCAT $(+25 \%, P<0 \cdot 05)$. Total extractable RNA amounts did not differ significantly between adipose tissue sites of both calf groups $(P=0 \cdot 26)$ or between the two groups of calves for all adipose tissue sites $(P=0 \cdot 12)$ : mean values were $73.9,61.8$ and $66.8 \mu \mathrm{g} / \mathrm{g}$ fresh tissue in PAT, OAT and SCAT respectively from PR calves and $61 \cdot 1,56 \cdot 8$, and $51 \cdot 0 \mu \mathrm{g} / \mathrm{g}$ fresh tissue in PAT, OAT and SCAT respectively from $\mathrm{R}$ calves (SEM 7.37).

TAG contents were higher $(+50 \%$ to $+70 \%)$ in internal adipose tissues (PAT and OAT) than in SCAT $(P<0.05$, Fig. 1A). They were lower in adipose tissues of $\mathrm{R}$ calves $(P=0.01$, Fig. 1A), especially in the visceral adipose tissues $(-15 \%$ in OAT, $P<0.01$, and $-13 \%$ in PAT, $P<0 \cdot 10)$.

\section{Lipoprotein lipase activity and $m R N A$ level in adipose tissues}

LPL activity was higher in internal adipose tissues than in SCAT $(+130 \%$ to $+170 \%, P<0 \cdot 05$, Fig. 1B). Moreover, LPL activity was more than 2-fold lower in adipose tissues of R calves ( $P<0.03$, Fig. 1B) which may explain, at least in part, the lower TAG content of adipose tissue from $\mathrm{R}$ calves (Fig. 1A). Indeed, TAG content was positively correlated with LPL activity when data of the three adipose sites were analysed together $(r=0.51, P<0.02)$. Northern blotting revealed two major LPL mRNA species in the bovine tissues of $3.5-3.8$ and $3 \cdot 2-3.4 \mathrm{~kb}$ respectively
(Fig. 2(A)). In some samples, a third species corresponding to a smaller LPL mRNA (around $1.7 \mathrm{~kb}$ ) was detected (results not shown) as previously described (Kirchgessner et al. 1987; Senda et al. 1987; Hocquette et al. 1998a). However, this species was not detected in a majority of tissues and therefore, was not quantified. LPL mRNA levels significantly differed between adipose tissue sites $(P=$ 0.0001). Indeed, PAT contained the highest amount of LPL mRNA in arbitrary densitometric units per $g$ fresh tissue $(P<0 \cdot 05$, Fig. 1C), per mg total extractable RNA or per $\mu g$ DNA, when compared with OAT or SCAT. LPL mRNA levels differed also significantly between PR and $\mathrm{R}$ calves $(P<0.05$, Fig. 1C). Indeed, mean values for LPL mRNA levels were 2 -fold (for PAT and OAT, $P<0 \cdot 10$ ) or 3 -fold (for SCAT, $P<0.05$ ) higher for calves of the PR group than for those of the R group (Fig. 1C).

\section{Biochemical and metabolic characteristics of muscles}

Isocitrate dehydrogenase activity, a characteristic of the oxidative muscle metabolism, total protein content, total DNA content and total extractable RNA (biochemical variables) were measured in samples of heart and seven skeletal muscles. Isocitrate dehydrogenase activity was the highest in oxidative muscles (heart, masseter, diaphragma) (Hocquette et al. 1997). Mean values of protein content ranged from 159 to $246 \mathrm{mg} / \mathrm{g}$ fresh tissue (SEM 7.8), the lowest values being observed in the heart and the highest values in the rectus abdominis (Table 1). Total DNA content and total extractable RNA of tissues (Table 1) were higher in oxidative muscles than in other skeletal muscles.

Isocitrate dehydrogenase activity was significantly higher in masseter from $\mathrm{R}$ than PR calves $(+71 \%, P<0.001)$ and lower in longissimus thoracis from $\mathrm{R}$ than $\mathrm{PR}$ calves $(-31 \%, P<0.01)$. Mean DNA content was $5 \%$ lower in

Table 1. Total protein, DNA and RNA contents in the heart and various skeletal muscles from preruminant (PR) and ruminant (R) calvest (Mean values with their standard errors for seven calves per group)

\begin{tabular}{|c|c|c|c|c|c|c|}
\hline \multirow{2}{*}{$\begin{array}{l}\text { Biochemical variables... } \\
\text { Calf group... }\end{array}$} & \multicolumn{2}{|c|}{$\begin{array}{l}\text { Total protein }(\mathrm{mg} / \mathrm{g} \text { fresh } \\
\text { tissue) }\end{array}$} & \multicolumn{2}{|c|}{ DNA ( $\mu \mathrm{g} / \mathrm{g}$ fresh tissue) } & \multicolumn{2}{|c|}{$\begin{array}{l}\text { Total extractable RNA } \\
\text { ( } \mu \mathrm{g} / \mathrm{g} \text { fresh tissue) }\end{array}$} \\
\hline & PR & $\mathrm{R}$ & PR & $\mathrm{R}$ & PR & $\mathrm{R}$ \\
\hline $\mathrm{H}$ & $169^{\mathrm{B}}$ & $159^{c} \ddagger$ & $1978^{A}$ & $1900^{\mathrm{a}}$ & $608^{A}$ & $606^{a}$ \\
\hline MA & $184^{\mathrm{B}}$ & $178^{c^{+}}$ & $1433^{\mathrm{B}}$ & $1423^{\mathrm{b}}$ & $363^{\mathrm{B}}$ & $447^{\mathrm{b} *}$ \\
\hline D & $170^{\mathrm{B}}$ & $170^{\mathrm{C}}$ & $1445^{\mathrm{B}}$ & $1367^{b}$ & $388^{\mathrm{B}}$ & $439^{b}$ \\
\hline RA & $231^{\mathrm{A}}$ & $246^{a}$ & $1097^{\mathrm{C}}$ & $1049^{\mathrm{C}} \dagger$ & $301^{\mathrm{B}}$ & $248^{c}$ \\
\hline TFL & $217^{A}$ & $220^{b}$ & $1108^{C}$ & $1080^{c}$ & $254^{\mathrm{B}}$ & $232^{c}$ \\
\hline ST & $179^{\mathrm{B}}$ & $167^{c}$ & $1145^{\mathrm{C}}$ & $1073^{c}$ & $218^{\mathrm{B}}$ & $251^{\mathrm{C}} \ddagger$ \\
\hline CT & $223^{A}$ & $226^{\mathrm{b}}$ & $1168^{\mathrm{C}}$ & $1115^{\mathrm{c}}$ & $302^{\mathrm{B}}$ & $250^{\mathrm{c} *}$ \\
\hline LT & $192^{\mathrm{B}}$ & \multirow[b]{2}{*}{$7 \cdot 8$} & $924^{\mathrm{D}}$ & $871^{d}$ & $303^{B}$ & $282^{c}$ \\
\hline \multirow{2}{*}{\multicolumn{2}{|c|}{$\begin{array}{l}\text { SEM } \\
\text { Statistical significance of effect of }(P<) \text { :§ }\end{array}$}} & & \multicolumn{2}{|c|}{$36 \cdot 9$} & \multicolumn{2}{|c|}{$40 \cdot 2$} \\
\hline & & & & \multicolumn{2}{|c|}{$40 \cdot 2$} \\
\hline G & \multirow{2}{*}{\multicolumn{2}{|c|}{$\begin{array}{l}0.44 \\
0.35\end{array}$}} & \multirow{2}{*}{\multicolumn{2}{|c|}{0.05}} & \multicolumn{2}{|c|}{0.91} \\
\hline C & & & & & \multicolumn{2}{|c|}{$0 \cdot 71$} \\
\hline M & \multicolumn{2}{|c|}{0.0001} & \multicolumn{2}{|c|}{0.0001} & \multirow{2}{*}{\multicolumn{2}{|c|}{0.62}} \\
\hline $\mathrm{G} \times \mathrm{M}$ & \multicolumn{2}{|c|}{0.48} & \multicolumn{2}{|c|}{0.98} & & \\
\hline
\end{tabular}

$\mathrm{H}$, heart; MA, masseter, D, diaphragma; RA, rectus abdominis; TFL, tensor fasciae latae; ST, semitendinosus; CT, cutaneous trunci; LT, longissimus thoracis. $\mathrm{A}, \mathrm{B}, \mathrm{C}, \mathrm{D}, \mathrm{a}, \mathrm{b}, \mathrm{c}, \mathrm{d}$ Mean values within a row with unlike superscript letters were significantly different: $(P<0.05)$.

Mean values were significantly different from those for PR calves: * $P<0.05$.

†For details of animals and procedures, see p. 434.

Mean values tended to be significantly different from those of $\mathrm{R}$ calves: $\ddagger P<0.10$

$\S G, C, M$, significant effects of group $(G)$ tested against calves within group, of calf $(C)$, of muscles (M) and of the group $\times m u s c l e ~ i n t e r a c t i o n ~(G \times M)$. 

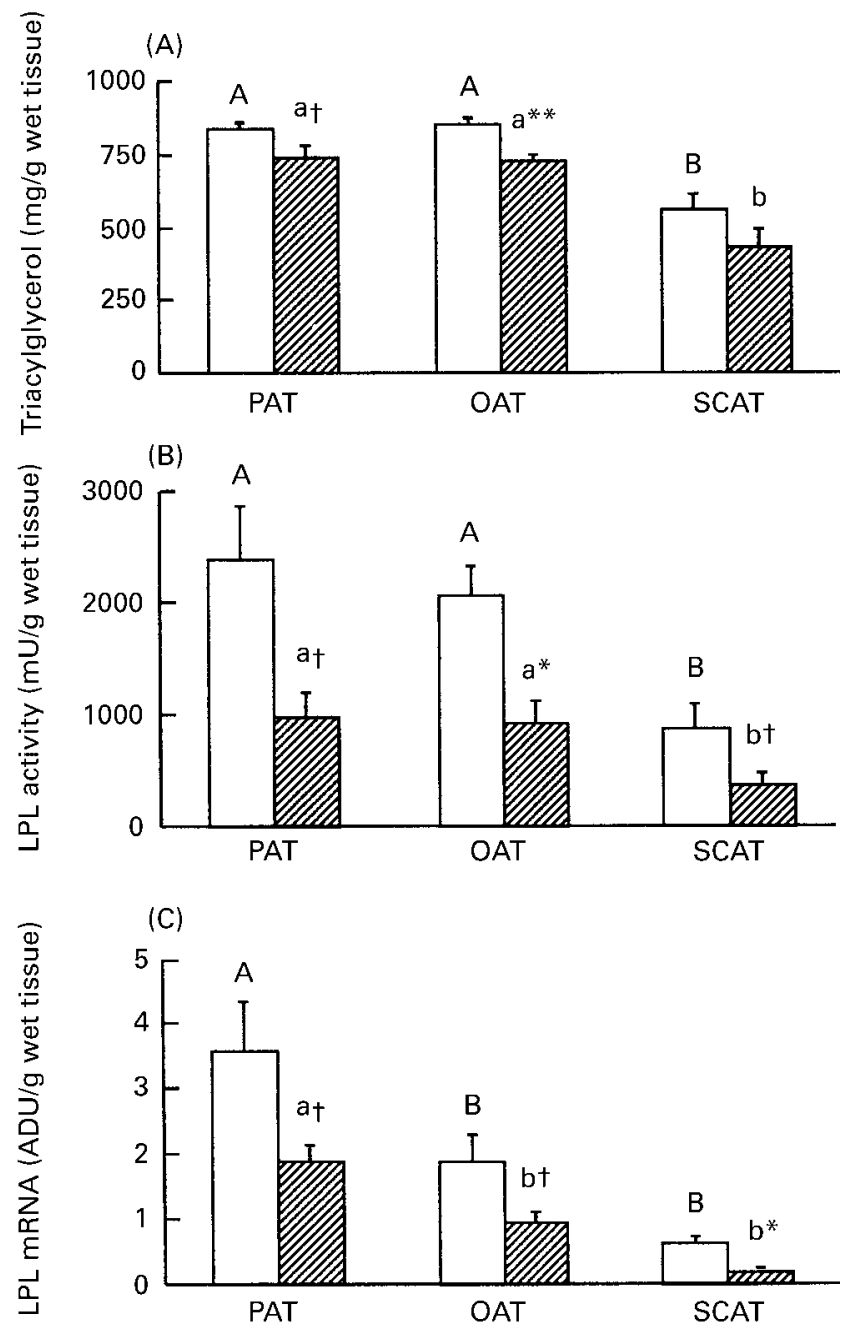

Fig. 1. (A) Triacylglycerol (TAG) content, (B) lipoprotein lipase (LPL) activity and (C) LPL mRNA level in adipose tissues from preruminant $(\square)$ and ruminant (四) calves. PAT, perirenal adipose tissue; OAT, omental adipose tissue; SCAT, subcutaneous adipose tissue; ADU, arbitary densitometric units. For details of diets and procedures, see pp. 434-435. Values are means for four to seven calves per group with their standard errors represented by vertical bars. $\mathrm{A}, \mathrm{B}, \mathrm{a}, \mathrm{b}$ Mean values within a group (preruminant or ruminant) with unlike superscript letters were significantly different $(P<0.05)$. Mean values were significantly different from those of preruminant calves: * $P<0.05$, ${ }^{* *} P<0.01$. Mean values tended to be significantly different from those of preruminant calves: $\dagger P<0.10$. The statistical significances $(P=)$ of effect of group tested against calves within group, of calf, of adipose tissue and of the groupxadipose tissue interaction were: $0.01,0.14,0.0001$ and 0.95 respectively for TAG content; $0.01,0.18,0.002$ and 0.19 respectively for LPL activity; and $0.04,0.11,0.0001$ and 0.25 respectively for LPL mRNA level.

muscles from $\mathrm{R}$ than PR calves $(P<0 \cdot 05$, Table 1$)$. Total extractable RNA was significantly higher in masseter $(+23 \%, P<0.05)$ and lower in cutaneus trunci $(-17 \%$, $P<0 \cdot 05$ ) for $\mathrm{R}$ than for PR calves (Table 1). No significant differences in tissue protein content were found between PR and R calves (Table 1). Similarly, no significant differences in TAG, phospholipids and total cholesterol were found in rectus abdominis muscle between $\mathrm{PR}$ and $\mathrm{R}$ calves (results not shown).
Lipoprotein lipase activity and lipoprotein lipase $m R N A$ level in muscles

LPL activity was higher in the heart and in masseter (the most oxidative muscles) than in other skeletal muscles (Fig. 3A). LPL activity was higher in masseter from $\mathrm{R}$ than PR calves $(+50 \%, P<0 \cdot 01)$. Inversely, LPL activity tended to be lower in the heart from the R compared with the PR calves (Fig. 3A).

As for adipose tissues, Northern blot analysis revealed two major LPL mRNA species in muscles (Fig. 2B). As for LPL activity, LPL mRNA levels (Fig. 3B) significantly differed among muscles $(P=0 \cdot 0001)$. Indeed, LPL mRNA level in the heart was $10->100$-fold higher than in the studied skeletal muscles $(P<0 \cdot 05)$. No effect of weaning could be observed in levels of LPL mRNA from muscles except in masseter, of which the mean value was higher $(+120 \%, P=0.01)$ for the R calves compared with the PR calves (Figs. 2B and 3B). The differences between muscles and between the two groups of calves were similar when values were expressed per $\mu \mathrm{g}$ total RNA or per $\mu \mathrm{g}$ DNA (results not shown).

\section{Discussion}

In ruminant animals at weaning, the liquid milk diet is replaced by solid foods based on cereals and hay. Studies on physiological consequences of this nutritional change have been focused on the development of ruminal fermentation, but to a limited extent on lipid metabolism in spite of its importance for the growth of the young calf (Hocquette \& Bauchart, 1999). Thus, consequences of weaning on LPL activity and gene expression were investigated in the present study, since LPL is considered as one of the major ratelimiting steps of energy delivery from lipoproteins to tissues and of partitioning of fat between their site of storage (adipose tissues) and their site of oxidation (muscles) (Olivecrona et al. 1991; Pethick \& Dunshea, 1993). The major result of this study is that LPL activity and expression were markedly reduced $63 \mathrm{~d}$ after the onset of weaning of the calf in adipose tissues but not in muscles.

\section{Lipoprotein lipase activity and gene expression in adipose tissues}

Adipose tissues are able to take up circulating fatty acids and to store them as TAG. One of the main sources of plasma fatty acids results from hydrolysis of the circulating TAG by LPL (Bauchart, 1993). Levels of LPL activity and gene expression are the highest in adipose tissues compared with other tissues in bovine animals (Hocquette et al. 1998a; present study), human subjects (Wion et al. 1987), rats (Semenkovich et al. 1989a), mice (Kirchgessner et al. 1987), guinea pigs (Braun \& Severson, 1992) or chickens (Cooper et al. 1989). Moreover, in the preruminant calf (Hocquette et al. 1998a) and in the adult cow (Chilliard \& Robelin, 1985), LPL activity differs among adipose tissue sites, which could reflect differences in metabolic rates. Indeed, visceral adipose tissues (PAT and OAT) have a higher LPL activity than SCAT which could explain, at least in part, their higher TAG contents. These differences are 
(A)

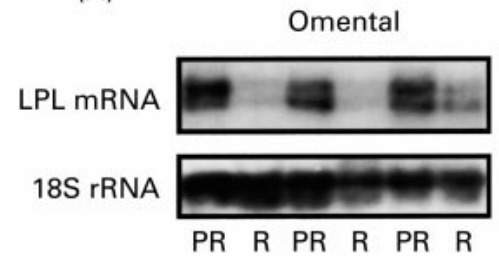

Perirenal

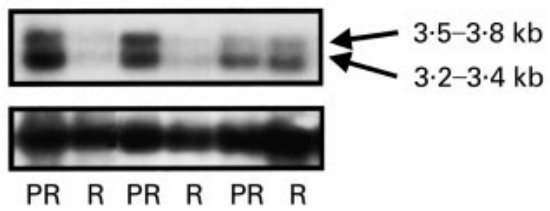

(B)

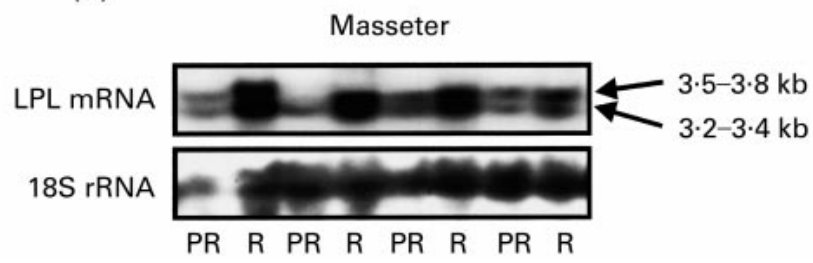

Fig. 2. Northern blot analysis of lipoprotein lipase (LPL) mRNA in (A) omental and perirenal adipose tissues and (B) masseter muscle from preruminant (R) or ruminant (R) calves. Total RNA was extracted from adipose tissue samples. RNA was then sizefractioned by $1.5 \%$ agarose gel electrophoresis and electrotransferred on a Genescreen membrane (New England Nuclear Life Science Products, Boston, MA, USA). The bovine LPL probe was labelled by random priming and hybridized before exposition to Hyperfilms MP (Amersham International, Amersham, Bucks, UK) with intensifying screens. Membranes were also hybridized with a probe for the rat 18S ribosomal RNA to take into account possible variations in the quantities of RNA loaded onto the gels. For further details of procedures, see p. 435.

partly associated with similar differences in LPL mRNA levels suggesting a pre-translational regulation of LPL expression.

A novel observation in the present study is that, in spite of similar net energy intakes and empty body weight gains, LPL activity and gene expression were reduced after weaning in calf adipose tissues but not in muscles, except in masseter. The decrease in LPL activity and gene expression in adipose tissues may explain, at least in part, their lower TAG content in R compared with PR calves. However, a decrease in glucose transporter expression (Hocquette et al. 1997) may also contribute to the lower TAG content in adipose tissues after weaning. In addition, lipogenesis in adipose tissues results mainly from long-chain fatty acid uptake in PR calves, and from de novo synthesis from acetate in $\mathrm{R}$ calves. Whatever the molecular mechanisms, our results indicate that the proportion of dietary energy which was stored as TAG in adipose tissues was lower in R calves than in PR calves. This may result, at least in part, from the lower availability of energy for lipid accretion, due to the higher energy utilisation by the digestive tract in $\mathrm{R}$ calves because of its development, its metabolic rate and the greater work of digestion.

A differential regulation of LPL between adipose and muscle tissues has already been described in the literature. For instance, fasting or underfeeding markedly reduce LPL activity in adipose tissues in both single-stomached and ruminant animal species, whereas variable changes or no changes in LPL activity were observed in muscles in similar nutritional conditions (for review, see Faulconnier et al. 1999). However, in the present study, variations in LPL activity and gene expression in adipose tissues may be explained by qualitative or quantitative dietary changes related to weaning.
Although net energy intake from birth onwards was carefully matched between the two groups of calves, energy partitioning between tissues probably differed between PR and $\mathrm{R}$ calves due to the development of the activity of the digestive tract after weaning. The consequences may be a lower level of available energy for fat accretion in adipose tissue of R calves, which may be linked to a lower LPL activity in this tissue as discussed later.

Another physiological factor to take into account is the kinetics of nutrient absorption, and availability of nutrients $16 \mathrm{~h}$ after the last meal in the present study. In PR calves, total intestinal chylomicron and VLDL production reaches a maximum $8 \mathrm{~h}$ after intake (for review, see Hocquette \& Bauchart, 1999) and TAG plasma concentration in the portal vein is still high $16 \mathrm{~h}$ after intake (Durand \& Bauchart, 1986). For R calves, absorption of nutrients is more regular and anyway, at a high level, $16 \mathrm{~h}$ after the last meal, due to the slow process of digestion of food by the micro-organisms present in the rumen (van Houtert, 1993). Thus, in this experiment, PR and especially $\mathrm{R}$ calves, were unlikely to be either in a fasting state or in a postprandial state, suggesting a limited influence of the time spent after the last meal.

Weaning is characterized in the calf by a decreased dietary supply of carbohydrates and fat, and an increased supply of volatile fatty acids and ketone bodies produced by the fermentation of food in the rumen. Among these nutrients, it can be speculated, from data available in other species, that the decrease in the absorbed fat may be responsible for the decrease in LPL expression (Jump \& Clark, 1999). Indeed, dietary fats were shown to modulate the expression of lipid-related genes in adipose cells (Ailhaud et al. 1996), such as the LPL gene (Auwerx et al. 1996). Activators of peroxisome proliferator-activated 


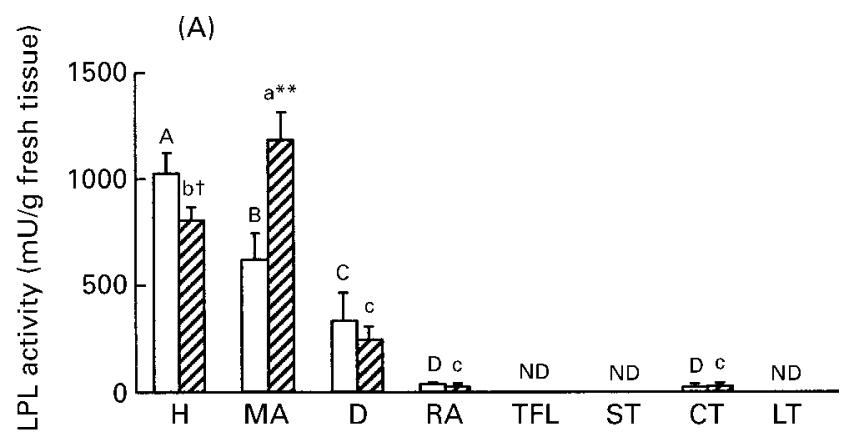

(B)

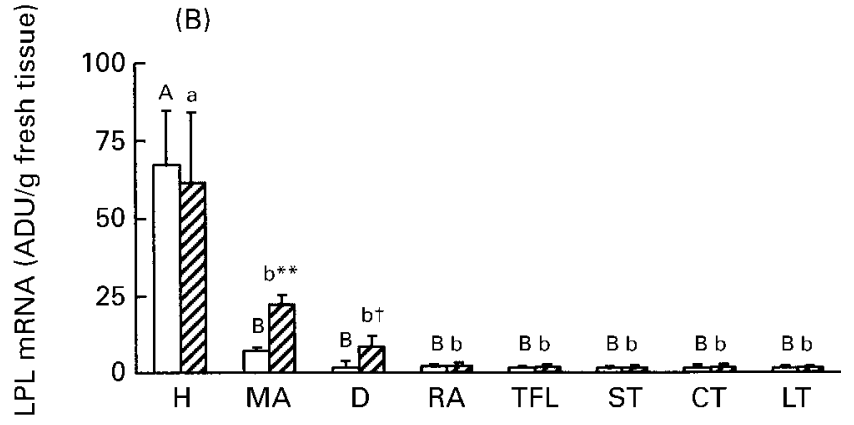

Fig. 3. (A) Lipoprotein lipase (LPL) activity, and (B) LPL mRNA level in heart and various skeletal muscles from preruminant ( $\square$ ) and ruminant $(\mathbb{O})$ calves. $\mathrm{H}$, heart; MA, masseter, D, diaphragma; $\mathrm{RA}$, rectus abdominis; LT, longissimus thoracis; ST, semitendinosus; TFL, tensor fasciae latae; CT, cutaneous trunci; ADU, arbitary densitometric units; ND, not detectable. For details of diets and procedures, see pp. 434-435. Values are means for seven animals per group (except for LPL activity in RA and CT, for which it was three or four animals per group) with their standard errors represented by vertical bars. A,B,C,D,a,b,c,dMean values within a group (preruminant or ruminant) with unlike superscript letters were significantly different $(P<0.05)$. Mean values were significantly different from those of preruminant calves: ${ }^{* *} P<0.05$. Mean values tended to be significantly different from those of preruminant calves: $\dagger P<0 \cdot 10$. The statistical significance $(P=)$ of effect of group tested against calves within group, of calf, of adipose tissue and of the groupxadipose tissue interaction were $0.78,0.0002,0.0001$ and 0.0001 respectively for LPL activity and $0.64,0.43,0.0001$ and 0.93 respectively for LPL mRNA level.

receptors $\gamma$ were indeed shown to direct a transcriptional response via a peroxisome proliferator-activated responsive element present in the LPL gene (Schoonjans et al. 1996). However, the regulation of LPL activity and expression by fatty acids is complex since it involves transcriptional and post-transcriptional mechanisms (Amri et al. 1996). Nevertheless, the direct regulation of LPL by fatty acids in cattle suggested in our present in vivo study needs to be fully analysed by in vitro approaches using bovine adipose tissue explants.

As previously described by Hugi \& Blum (1997), insulinaemia tended to be higher in PR calves fed a lactoserich milk substitute than in $\mathrm{R}$ calves fed a solid-based diet. Insulin is well known to stimulate LPL activity (Braun \& Severson, 1992) by increasing LPL mRNA levels (Ong et al. 1988), especially by post-translational mechanisms (Semenkovich et al. 1989b; Raynolds et al. 1990). In the present study, the greater insulinaemia in PR calves may have stimulated LPL activity in adipose tissues by one of these mechanisms.
As previously described (Hugi \& Blum, 1997), plasma triiodothyronine was lower in $\mathrm{R}$ calves than in PR calves. This decrease in plasma concentrations of thyroid hormones induced by weaning may regulate LPL activity in adipose tissue of $\mathrm{R}$ calves. Indeed, it was shown that heparinelutable LPL was lower in subcutaneous adipose tissue from hypothyroid patients than from control human subjects, but total LPL activity was similar between the two groups (Pykalisto et al. 1976). Moreover, adipocytes from hypothyroid rats were shown to exhibit higher LPL activity and protein content than those from control rats (Kern et al. 1996).

Finally, in our present study, decrease in dietary glucose supply at weaning could down-regulate other genes coding for enzymes involved in lipid metabolism such as fatty acid synthase (for review, see Ferré, 1999) or hormone-sensitive lipase (Raclot et al. 1998). This might explain why differences in LPL activity between PR and R calves $(+130 \%$ on average) did not match differences in TAG contents within adipose tissues ( $+20 \%$ on average). However, regulation of gene expression by glucose remains to be analysed further in ruminant animals.

\section{Lipoprotein lipase activity and gene expression in muscles}

LPL activity and gene expression have been quantified in the heart and in several skeletal muscles representing a panel of oxidative, glycolytic or mixed muscles. As previously observed (Hocquette et al. 1998a), LPL activity was higher in oxidative than in glycolytic muscles. Indeed, the ability of a muscle to hydrolyse plasma TAG by LPL would be, at least in part, co-ordinated with the ability of the muscle to completely oxidize the fatty acids within mitochondria. In the present study, the large differences in LPL activity between muscles were also observed for LPL mRNA levels. This suggests a major transcriptional regulation of the LPL gene, which does not exclude other mechanisms, such as intracellular activation (by dimerisation and glycosylation) and turnover (steady-state between synthesis, secretion into the extracellular medium or catabolism by the lysosomal pathway) of LPL (Braun \& Severson, 1992; Kern et al. 1996).

Although fatty acids were shown to up-regulate transcription of genes coding for proteins involved in fat metabolism in myocytes (Van der Lee et al. 2000), our present in vivo experiment indicates that the reduction in dietary fat supply at weaning did not significantly affect LPL activity or expression in heart and most muscles in the calf. The significant increase in LPL activity and gene expression was only noted in masseter in R compared with PR calves. This change, associated with an increase in isocitrate dehydrogenase activity, confirms the positive metabolic relationships between the ability of a given muscle to take up fatty acids (a process controlled in part by LPL activity) and its ability to oxidize them by the Krebs cycle (assessed by isocitrate dehydrogenase activity). Masseter, located in the cheek, is increasingly active after weaning because it is strongly involved in chewing of solid feeds. This muscle-specific physiological change induces a late conversion of some type IIC muscular fibres into type I fibres, as an adaptative response to forage intake and 
rumination (Picard et al. 1996). Thus, our results confirm the idea that local contractile activity is able to induce an increase in LPL expression (Hamilton et al. 1998).

In conclusion, our present study demonstrates that weaning reduces calf LPL activity in various adipose tissues, which may contribute to their lower TAG contents after weaning. The effects of weaning on LPL activity in the muscle tissues were not significant except in the masseter, probably because of its contractile activity for solid food chewing. All these results indicate an in vivo nutritional and/or hormonal regulation of LPL activity and expression in adipose tissues, but not in muscles.

\section{Acknowledgements}

We thank Nicole Guivier for her skilled technical assistance, Robert Jailler, Sylvie Rudel and their group for the management of the animals, and Roland Jailler and his group for the management of the slaughterhouse.

\section{References}

Ailhaud G, Amri EZ \& Grimaldi PA (1996) Fatty acids and expression of lipid-related genes in adipose cells. Proceedings of the Nutrition Society 55, 151-154.

Amri EZ, Teboul L, Vannier C, Grimaldi PA \& Ailhaud G (1996) Fatty acids regulate the expression of lipoprotein lipase gene and activity in preadipose and adipose cells. Biochemical Journal 314, 541-546.

Auwerx J, Schoonjans K, Fruchart JC \& Staels B (1996) Transcriptional control of triglyceride metabolism: fibrates and fatty acids change the expression of the LPL and apo C-III genes by activating the nuclear receptor PPAR. Atherosclerosis 124, Suppl., S29-S37.

Bauchart D (1993) Lipid absorption and transport in ruminants. Journal of Dairy Science 76, 3864-3881.

Bonnet M, Faulconnier Y, Fléchet J, Hocquette JF, Leroux C, Langin D, Martin P \& Chilliard Y (1998) Messenger RNAs encoding lipoprotein lipase, fatty acid synthase and hormonesensitive lipase in the adipose tissue of underfed-refed ewes and cows. Reproduction Nutrition and Development 38, 297-307.

Braun JEA \& Severson DL (1992) Regulation of synthesis, processing and translocation of lipoprotein lipase. Biochemical Journal 287, 337-347.

Chilliard Y \& Robelin J (1985) Activité lipoprotéine-lipasique de différents dépôts adipeux et ses relations avec la taille des adipocytes chez la vache tarie en cours d'engraissement ou en début de lactation (Lipoprotein lipase activity in different adipose tissues and relations with the adipocyte size in the dry cow during fattening or at the beginning of the lactation). Reproduction Nutrition Développement 25, 287-293.

Cooper DA, Stein JC, Strieleman PJ \& Bensadoun A (1989) Avian adipose lipoprotein lipase: cDNA sequence and reciprocal regulation of mRNA levels in adipose and heart. Biochimica et Biophysica Acta 1008, 92-101.

Durand D \& Bauchart D (1986) Variations nycthémérales de la lipémie et de la glycémie au niveau des voies afférentes et éfférentes du foie chez le veau préruminant (Nycthemeral variations in lipaemia and glycaemia in afferant and efferant hepatic vessels in the preruminant calf). Reproduction Nutrition Development 26, 371-372.

Faulconnier Y, Bonnet M, Bocquier F, Leroux C, Hocquette JF, Martin P \& Chilliard Y (1999) Régulation du métabolisme lipidique des tissus adipeux et musculaires chez le ruminant.
Effet du niveau alimentaire et de la photopériode (Regulation of lipid metabolism of adipose tissue and muscle in ruminants. Effects of feeding level and photoperiod). INRA Productions Animales 12, 287-300.

Ferré P (1999) Regulation of gene expression by glucose. Proceedings of the Nutrition Society 58, 621-623.

Girard J, Ferré P, Pégorier JP \& Duée PH (1992) Adaptations of glucose and fatty acid metabolism during perinatal period and suckling-weaning transition. Physiological Reviews 72, 507-562.

Hamilton MT, Etienne J, McClure W, Pavey BS \& Holloway AK (1998) Role of local contractile activity and muscle fiber type on LPL regulation during exercise. American Journal of Physiology 275, E1016-E1022.

Hocquette JF \& Bauchart D (1999) Intestinal absorption, blood transport and hepatic and muscle metabolism of fatty acids in preruminant and ruminant animals. Reproduction Nutrition Development 39, 27-48.

Hocquette JF, Castiglia-Delavaud C, Graulet B, Ferré P, Picard B \& Vermorel M (1997) Weaning marginally affects glucose transporter (GLUT4) expression in calf muscles and adipose tissues. British Journal of Nutrition 78, 251-271.

Hocquette JF, Graulet B, Castiglia-Delavaud C, Bornes F, Lepetit $\mathrm{N}$ \& Ferré P (1996) Insulin-sensitive glucose transporter transcript levels in calf muscles assessed with a bovine GLUT4 cDNA fragment. International Journal of Biochemistry and Cell Biology 28, 795-806.

Hocquette JF, Graulet B \& Olivecrona T (1998a) Lipoprotein lipase activity and mRNA levels in bovine tissues. Comparative Biochemistry and Physiology B 121, 201-212.

Hocquette JF, Ortigues-Marty I, Pethick DW, Herpin P \& Fernandez X (1998b) Nutritional and hormonal regulation of energy metabolism in skeletal muscles of meat-producing animals. Livestock Production Science 56, 115-143.

Hugi D \& Blum JW (1997) Changes of blood metabolites and hormones in breeding calves associated with weaning. Journal of Veterinary Medecine - Series A 44, 99-108.

Jarrige R (1989) Ruminant Nutrition Recommended Allowances and Feed Tables, Paris: Institut National de la Recherche Agronomique, pp. 389.

Jump DB \& Clarke SD (1999) Regulation of gene expression by dietary fat. Annual Review of Nutrition 19, 63-90.

Kauffman RG, Habel RE, Smulders FJM, Hartman W \& Bergstrom PL (1990) Recommended terminology for the muscle commonly designated longissimus dorsi. Meat Science 28, 259-265.

Kern PA, Ranganathan G, Yukht A, Ong JM \& Davis RC (1996) Translational regulation of lipoprotein lipase by thyroid hormone is via a cytoplasmic repressor that interacts with the $3^{\prime}$ untranslated region. Journal of Lipid Research 37, 2332-2340.

Kirchgessner TG, Svenson KL, Lusis AJ \& Schotz MC (1987) The sequence of cDNA encoding lipoprotein lipase. A member of a lipase gene family. Journal of Biological Chemistry 262, 8463-8466.

Kouame KG, Troccon JL, Patureau-Mirand P, Journet M \& Pion R (1984) Nutrition des veaux au cours du sevrage. I Evolution de la consommation d'aliments et des concentrations sanguines de divers métabolites énergétiques (Calf nutrition during the weaning period. I. Variations in feed intake and blood levels of energetic metabolites). Annales de Zootechnie 33, 427-444.

Olivecrona T, Bengtsson-Olivecrona G, Chajek-Shaul T, Carpendier Y, Deckelbaum R, Hultin M, Peterson J, Patsch J \& Vilaro S (1991) Lipoprotein lipase. Sites of synthesis and sites of action. Atherosclerosis Review 22, 21-25.

Ong JM, Kirchgessner TG, Schotz MC \& Kern PA (1988) Insulin increases the synthetic rate and messenger RNA level of 
lipoprotein lipase in isolated rat adipocytes. Journal of Biological Chemistry 263, 12933-12938.

Pearce J \& Unsworth EF (1980) The effects of diet on some hepatic enzyme activities in the pre-ruminant and ruminating calf. Journal of Nutrition 110, 255-261.

Pethick DW \& Dunshea FR (1993) Fat metabolism and turnover. In Quantitative Aspects of Ruminants Digestion and Metabolism, pp. 291-311 [JM Forbes and J France, editors]. Wallingford: CAB International.

Picard B, Gagnière H \& Geay Y (1996) Contractile differenciation of bovine masseter muscle. Basic and Applied Myology 6, $361-372$.

Pykalisto O, Goldberg AP \& Brunzell JD (1976) Reversal of decreased human adipose tissue lipoprotein lipase and hypertriglyceridemia after treatment of hypothyroidism. Journal of Clinical Endocrinology and Metabolism 43, 591-600.

Quigley JD, Caldwell LA, Sinks GD \& Heitmann RN (1991a) Changes in blood glucose, nonesterified fatty acids, and ketones in response to weaning and feed intake in young calves. Journal of Dairy Science 74, 250-257.

Quigley JD, Smith ZP \& Heitmann RN (1991b) Changes in plasma volatile fatty acids in response to weaning and feed intake in young calves. Journal of Dairy Science 74, 258-263.

Raclot T, Dauzats M \& Langin D (1998) Regulation of hormonesensitive lipase expression by glucose in 3T3-F442A adipocytes. Biochemical and Biophysical Research Communications 245, $510-513$.

Raynolds MV, Awald PD, Gordon DF, Gutierrez-Hartmann A, Rule DC, Wood WM \& Eckel RH (1990) Lipoprotein lipase gene expression in rat adipocytes is regulated by isoprotenerol and insulin through different mechanisms. Molecular Endocrinology 4, 1416-1422.

Schoonjans K, Peinado-Onsurbe J, Lefebvre AM, Heyman RA, Briggs M, Deeb S, Staels B \& Auwerk J (1996) PPAR $\alpha$ and
PPAR $\gamma$ activators direct a distinct tissue-specific transcriptional response via a PPRE in the lipoprotein lipase gene. EMBO Journal 15, 5336-5348.

Semenkovich CF, Chen SH, Wims M, Luo CC, Li WH \& Chan L (1989a) Lipoprotein lipase and hepatic lipase mRNA tissue specific expression, developmental regulation and evolution. Journal of Lipid Research 30, 423-431.

Semenkovich CF, Wims M, Noe L, Etienne J \& Chan L (1989b) Insulin regulation of lipoprotein lipase activity in 3T3-L1 adipocytes is mediated at posttranscriptional and posttranslational levels. Journal of Biological Chemistry 264, 9030-9038.

Senda M, Oka K, Brown WV, Qasba PK \& Furuichi Y (1987) Molecular cloning and sequence of a cDNA coding for bovine lipoprotein lipase. Proceedings of the National Academy of Sciences, USA 84, 4369-4373.

Van der Lee KAJM, Vork MM, De Vries JE, Willemsen PHM, Glatz JFC, Reneman RS, Van der Vusse GJ \& Van Bilsen M (2000) Long-chain fatty acid-induced changes in gene expression in neonatal cardiac myocytes. Journal of Lipid Research 41, 41-47.

van Houtert MFJ (1993) The production and metabolism of volatile fatty acids by ruminants fed roughages: A review. Animal Feed Science and Technology 43, 189-225.

Vermorel M, Bouvier JC, Thivend P \& Toullec R (1974) Utilisation énergétique des aliments d'allaitement par le veau préruminant à l'engrais à différents poids (Energy utilization of liquid milk replacers by veal calves). In Proceedings of the 6th Symposium on Energy Metabolism, Stuggart (Germany), EAAP Publication no. 14, pp. 143-146 [KH Menke, H-J Lantzch and JR Reichl, editors]. Universitat Hohenheim, Dokumentationsstelle, Stuggart, Germany: EAAP.

Wion KL, Kirchgessner TG, Lusis AJ, Schotz MC \& Lawn RM (1987) Human lipoprotein lipase complementary DNA sequence. Science 235, 1638-1641. 